work on disease, and indeed much of it deals not with the past but with procedure in use among primitive peoples today. Trepanation is discussed at length by Lisowski and by Margetts, but little or nothing is added to Guiard's work. In at least two areas where trepanation was practised both in the past and recently (the Sudan and Indonesia), Shaman-like priests are initiated in a ceremony described as "the opening of the head". It is curious that nobody has attempted to see if there is any connexion.

The final section deals with mental abnormality in antiquity. Literary sourees are drawn on heavily; the cuneiform inscriptions as interpreted by Kinnier Wilson revealing a particularly rich complex of ideas regarding mental illness in the ancient Middle East.

The book is exceptionally well edited, there being little overlap between the work of so many writers. It contains invaluable bibliographies and it demonstrates how much has been accomplished, and how much remains to be achieved, particularly in the quantitative field. For many years to come it will be an indispensable tool in the hand of everyone working in the field of palaeopathology. H. Hughes

\section{EVOLUTION OF THE MEDICINE MAN}

\section{The Healers}

The Doctor, Then and Now. By Kurt Pollak, in collaboration with E. Ashworth Underwood. Pp. x+246+ 32 plates. (London: Thomas Nelson and Sons, Ltd, 1968.) $50 s$.

Concomitant with a growing interest in historical medicine and individual doctors of the past, numerous aspects of the art of healing have been studied of late by medical historians and several books have been published on the subject. This book has original features which call for special mention.

Dr Kurt Pollak, an Austrian, a lecturer in the Academy of Military Medicine in Bonn, published Die Jünger des Hippokrates : Der Weg des Arztes durch sechs Jahrtausende (The Descendants of Hippocrates: The Progress of the Doctor through Six Thousand Years) in 1963. It is not a history of medicine, but an account of the evolution of the medical practitioner from primitive times to the present day in the main civilizations of the world. In the translation many passages relating to German practitioners and their training have been either eliminated or replaced by corresponding information relating to British practice. The first half of the book is virtually by Dr Pollak; the second half is substantially written by Dr Underwood.

It was necessary to shorten the book and further deletions were made by the publishers in Dr Pollak's version; the additions concerning British practice were retained. The deleted portions consist largely of quotations and further German details which are of interest only to specialists, and can be consulted in the original German version.

This book has involved much original research and scholarship by the joint authors. It surveys the progress of doctors almost "from China to Peru".

The "doctor" who trepaned the cave-men is followed by the medicine man; then there is a careful study of Assyrian and Egyptian doctors based on the Code of Hammurabi and the Rosetta stone, with a valuable account of Egyptian papyri with medical references. Next come doctors in India, China and Japan; those in Greece and Rome, well known and of paramount importance, inasmuch as they include Hippocrates and Galen, follow. Erom St Luke the narrative passes to the Middle Ages, to Paracelsus, Vesalius, the founding of the College of Physicians, the United Company of Barber-Surgeons,
Thomas Vicary, Clowes and Wiseman. Then there follow the apothecaries and their royal charter, hall and Worshipful Society, William Harvey, Sydenham, French medicine and doctors, Mesmer and magnetism, Johann Peter Frank and a Police Force for Health, medical reform, scientific medical practitioners, specialists, general practitioners and certain research workers. Sections of the book are devoted to the struggle of women to enter the medical profession, to political and literary doctors, and to the British National Health Service.

The outlook is wide but, with the exception of Frank, relates to clinicians, specialists and research workers. The reference to Sir John Simon on page 184 concerns medical education. The influence of exponents of preventive medicine does not come within Dr Pollak's purview. Dr Underwood, however, does emphasize the importance of health and hygiene in his concluding pages.

Arthur MacNalty

\section{AMERICAN MEDICAL LICENCES}

\section{Medical Licensing in America}

By Richard Harrison Shryock. Pp. xi+124. (Baltimore, Md.: The Johns Hopkins Press; London: Oxford University Press, 1967.) 52s. 6d.

ONE of the most vital aspects of a profession is the method of control that society and the profession itself have imposed on its practitioners. It is of central importance to the educational system which produces the potential licensee, it reflects the development of the subject under consideration, and it is influenced by a multitude of social and cultural factors.

This is especially true of the medical profession and in no other is licensing of such crucial importance to all concerned. It is therefore surprising that little has been written on the evolution of medical licensing, and Dr Shryock's book on the United States is the first to consider a small part of it in a scholarly fashion. It is, in fact, a remarkably complicated story to tell, ranging in time as it does from the earliest primitive settlers to the present day, in a country of great topographical diversity. Dr Shryock traces the development of standards for the practice of medicine and, being a social historian, he is able to relate this with skill and perception to background social influences. Moreover, he outlines briefly the arrangements in the other countries by which America was influenced, and, to give his analysis even greater depth and significance, he adds a comparative study of the, legal profession.

The result is an excellent account of how medical societies, medical schools and finally state boards have each taken a hand in licensing American doctors. The outcome of this almost experimental process is of the greatest value to those in other countries who may be unsatisfied with present arrangements and who wish to evaluate other methods. Admittedly, conditions have been and still are unique in America, but there have been enough general principles for the events to be pertinent elsewhere. The greatest fascination, however, is to observe how the medical profession gradually developed its restraints, set against the cultural evolution of a young and vigorous poople. They inevitably copied from Britain and from the Continent, but at the same time domestic regulations peculiar to their own circumstances were established.

Dr Shryock's book is documented with scholarly precision and should be read by all who are concerned with medical education today. As he points out in conclusion, "Iicensing procedures are still far from perfect" (page 115); it follows that to plan for the further evolution that is necessary, it is essential to know what has been tried already. 